\title{
Effects of addition of fluorine in diets differing in protein content on urinary fluoride excretion, clinical chemistry and thyroid hormones in calves
}

\author{
Jayant Lohakare ${ }^{1}$, Ashok Kumar Pattanaik²
}

\author{
${ }^{1}$ College of Animal Life Sciences, Kangwon National University, Chuncheon, South Korea. \\ ${ }^{2}$ Clinical and Pet Nutrition Laboratory, Division of Animal Nutrition, Indian Veterinary Research Institute, Izatnagar, India.
}

\begin{abstract}
In order to compare the effects of addition of fluorine (F) in diets differing in protein content on the urinary F excretion, blood profile and thyroid hormones, 30 crossbred calves (6-8 months) initially exposed to different protein levels were allotted into six groups in a $3 \times 2$ factorial design. The factors included three different levels of protein: normal (NP; $100 \%$ ), low (LP; 75\%), and high (HP; 125\%) besides two levels of supplemental fluorine (as sodium fluoride) at $0 \mathrm{or} 200 \mathrm{mg} / \mathrm{kg}$ diet. The animals were fed a wheat straw-based diet for $210 \mathrm{~d}$. Feeding NP diets decreased urinary fluoride excretion, measured at $42 \mathrm{~d}$ intervals, compared with LP diets. Blood levels of hemoglobin and haematocrit, measured at $70 \mathrm{~d}$ intervals, were not affected by either protein or fluorine levels, but period differences were apparent. Serum levels of urea, alkaline phosphatase and $\mathrm{F}$ showed greater increase in groups supplemented with $\mathrm{F}$ than in those without it; however, serum calcium was higher in the latter. Serum tri-iodo-thyronine and thyroxine levels were higher in HP and NP fed calves than animals on LP diets, respectively. The animals fed LPF have higher urinary F as compared with animals fed NPF, but were not different from the group fed HPF. The blood and serum variables indicated that there is no extra protection against susceptibility to F toxicity upon feeding of 25 percent higher protein than requirements.
\end{abstract}

Key Words: blood, cattle, concentrate, fluorosis, sodium fluoride, urine

\section{Introduction}

Chronic fluoride (F) toxicity (fluorosis) is a global health problem and is endemic in different parts of India (Choubisa, 2001; Chaudhary et al., 2008; Raghavachari, 2008; Chaudhary et al., 2009). Various compounds have been tried to alleviate fluorosis viz. calcium, phosphorus, aluminum, sodium chloride, lysine, diethylstilboestrol, oxytetracycline, vitamin $\mathrm{C}$, molybdenum, copper, iron, boron, tungsten, vanadium, selenium, glutamine, cystine and glucocorticoids (NAS, 1974; Parker et al., 1979; Wheeler \& Feel, 1983; Bharti et al., 2008). Dietary stress is known to affect skeletal fluorosis especially malnutrition, low protein, calcium and vitamin C (Wheeler \& Feel, 1983; He et al., 2008; Wang et al., 2008). Reduction of protein intake increases the amount of $\mathrm{F}$ retained in the body (Junkkarinen \& Kreula, 1976; He et al., 2008; Wang et al., 2008). An elevated deposition of $F$ in bone was also reported in guinea pigs fed low protein diets (Parker et al., 1979). Conversely, a depressive effect of high protein diets on the F retention primarily because of enhanced urinary excretion has been reported in rats (Boyde \& Cerklewski, 1987). Tooth wear has been shown to be beneficially influenced by protein supplementation in industry-fluorosed goats (Wang et al., 1994). Results on similar lines suggesting a reduction in $\mathrm{F}$ deposition in bones of pigs fed high protein diets as compared with low protein diets was also reported (Rys, 1973). A series of studies conducted with mice (Chinoy et al., 2005a,b; Chinoy et al., 2006), rats (He et al., 2008; Chen et al., 2009) and rabbits (Wang et al., 2008) have put forth the importance of dietary protein on the susceptibility to varied adverse impacts of fluorosis.

However, these beneficial effects of protein have not been explored in detail with livestock. Dietary protein levels as such have been shown to affect performance of crossbred calves (Lohakare et al., 2006) and diets low in protein may accentuate $\mathrm{F}$ retention and toxicity and retard growth in calves (Lohakare et al., 2010; 2011).

Another important aspect of $\mathrm{F}$ toxicity is its influence on thyroid metabolism. There are reports that high dietary $\mathrm{F}$ affects thyroid functioning, which is reflected in decreases in serum tri-iodo-thyronine $\left(\mathrm{T}_{3}\right)$ and thyroxine $\left(\mathrm{T}_{4}\right)$ levels (Cinar \& Selcuk, 2005; Zhan et al., 2006). In a recent study, Wang et al. (2009) demonstrated that excessive ingestion of $\mathrm{F}$ by rats damages the structure of thyroid gland and alters thyroid hormones levels in serum. Further, and more importantly, the authors concluded that dietary protein levels play key roles in thyroid dysfunction induced by F. This has got immense relevance to farm animal nutrition in tropics where there is a perpetual deficiency of quality feed 
resources predisposing the animals to periodic nutrient (protein and/or energy) deficiency. However, there is a dearth of information on the possible existence of such interaction between dietary protein and $\mathrm{F}$ in ruminant livestock. Hence, the present study was conducted to investigate the possible role of protein nutrition on the susceptibility as well as protective action against bovine fluorosis by regularly monitoring urinary $\mathrm{F}$ excretion, selective blood biochemical components and thyroid hormones in crossbred calves exposed to long-term high dietary F.

\section{Material and Methods}

Thirty crossbred male calves (Bos taurus $\times$ Bos indicus) aged 6-8 months (avg. $104 \mathrm{~kg} \mathrm{BW)} \mathrm{initially} \mathrm{exposed} \mathrm{to}$ different planes of protein nutrition for about 100 days were divided into six groups in a $3 \times 2$ factorial design. The factors included three different levels of protein normal (NP; 100\%), low (LP; 75\%), and high (HP; 125\%) as per Kearl (1982) recommendations - and two levels of supplemental fluorine as sodium fluoride $(\mathrm{NaF})$ at $0(\mathrm{~F}-)$ or $200(\mathrm{~F}+) \mathrm{mg} / \mathrm{kg}$ diet. The calves in the NP group received

Table 1 - Ingredient composition (\%) of the concentrate supplements ${ }^{1}$

\begin{tabular}{lccc}
\hline & \multicolumn{3}{c}{ Concentrate mixture (CM) } \\
\cline { 2 - 4 } Ingredients & $\begin{array}{l}\text { Normal protein } \\
\text { (CM1 \& CM2) }\end{array}$ & $\begin{array}{c}\text { Low protein } \\
\text { (CM3 \& CM4) }\end{array}$ & $\begin{array}{c}\text { High protein } \\
\text { (CM5 \& CM6) }\end{array}$ \\
\hline Maize & 47 & 50 & 42 \\
Soybean meal & 25 & 15 & 38 \\
Wheat bran & 25 & 32 & 17 \\
Mineral mixture & 2 & 2 & 2 \\
Salt & 1 & 1 & 1 \\
Nutritional value (calculated) & & \\
Crude protein (\%) & 20.50 & 16.80 & 25.33 \\
ME (Mcal/kg) & 2.77 & 2.74 & 2.79 \\
\hline
\end{tabular}

${ }^{1}$ Added vitamin mix at $20 \mathrm{~g}$ per $100 \mathrm{~kg}$, containing 50,000 IU of vitamin A and 5,000 IU of vitamin D3 per $\mathrm{g}$.

${ }^{2}$ Moisture (maximum) - $70 \mathrm{~g} \mathrm{~kg}^{-1}$; calcium (minimum) - $280 \mathrm{~g} \mathrm{~kg}^{-1}$; phosphorus (minimum) - $120 \mathrm{~g} \mathrm{~kg}^{-1}$; iron - $5 \mathrm{~g} \mathrm{~kg}^{-1}$; iodine - $0.26 \mathrm{~g} \mathrm{~kg}^{-1}$; copper - $0.77 \mathrm{~g} \mathrm{~kg}^{-1}$; cobalt - $0.13 \mathrm{~g} \mathrm{~kg}^{-1}$ (all minimum levels); fluorine (maximum) - $0.40 \mathrm{~g} \mathrm{~kg}^{-1}$.
$100 \%$ of the protein requirements, whereas calves in LP and $\mathrm{HP}$ groups received $25 \%$ lower and higher $\mathrm{CP}$ than the requirements, respectively. The three groups of calves were fed three differently compounded isoenergetic concentrate mixtures having different crude protein $(\mathrm{CP})$ concentrations. The animals were fed the respective concentrate mixture (Tables 1 and 2), with or without $\mathrm{F}$, along with wheat straw to supply varied amount of crude protein (CP) but with apparently similar level of metabolizable energy (ME) during the experimental period of 210 days. The calves were individually offered weighed quantities of the respective concentrate mixtures at $9 \mathrm{~h} 00$ daily. The quantity of roughage, offered at $11 \mathrm{~h} 00$ daily, was adjusted at about $120 \%$ of the previous day intake to ensure ad libitum consumption.

All the calves were housed individually in a wellventilated shed having individual feeding and watering arrangements. Clean drinking water was provided to all the calves once each in morning and afternoon. They were dewormed at the start by using broad-spectrum anthelmintics and were vaccinated against prevalent contagious diseases.

Fluoride content was determined by a fluoride selectiveion electrode following procedures described by Tusl for urine and concentrate mixture (Tusl, 1970; 1972). The F content in wheat straw was determined by the method of Villa(Villa, 1979).

Urinary excretion of $\mathrm{F}$ was monitored at regular intervals to assess the impact of exposure of $F$ through feeds. The animals were kept in the metabolic cages and urine was collected prior to feeding and watering at intervals of approximately six weeks. To minimize bacterial contamination, the mid-stream urine sample of a single voiding was taken. The urine samples were then stored in clean plastic bottles containing $0.2 \mathrm{~g}$ of ethylene diamine tetra-acetic acid per $100 \mathrm{~mL}$ urine under refrigeration until analysis. The ionic F concentration in urine was estimated by using a fluoride ion specific electrode (Orion-model 290 A) (Tusl, 1970).

Table 2 - Chemical composition of feeds and fodder (percentage on a DM basis)

\begin{tabular}{|c|c|c|c|c|c|c|c|}
\hline Attributes $^{1}$ & CM1 & $\mathrm{CM} 2$ & CM3 & CM4 & CM5 & CM6 & Wheat straw \\
\hline Organic matter & 90.65 & 91.22 & 92.06 & 91.60 & 91.94 & 90.34 & 91.78 \\
\hline Crude protein & 19.50 & 19.45 & 16.00 & 15.85 & 24.55 & 25.01 & 3.17 \\
\hline Ether extract & 4.83 & 4.91 & 5.11 & 5.13 & 4.30 & 4.32 & 1.79 \\
\hline Ash & 9.35 & 8.78 & 7.94 & 8.40 & 8.06 & 9.66 & 8.22 \\
\hline Nitrogen-free extract & 59.86 & 60.44 & 63.90 & 63.52 & 56.03 & 53.88 & 50.67 \\
\hline Calcium & 1.30 & 1.02 & 1.11 & 1.32 & 1.10 & 1.10 & 1.00 \\
\hline Phosphorus & 1.04 & 0.86 & 0.93 & 0.98 & 0.86 & 0.88 & 0.26 \\
\hline $\mathrm{F}(\mathrm{mg} / \mathrm{kg})$ & 14.52 & 294.65 & 17.88 & 302.24 & 15.13 & 299.42 & 17.37 \\
\hline
\end{tabular}

${ }^{1}$ Analyses were performed in triplicate.

$\mathrm{CM}$ - concentrate mixture. 
Blood samples were collected from all animals in each group at the beginning and at regular ( $\sim 70$ days) intervals, from the jugular vein into two tubes, one with and the other without anticoagulant. The anticoagulated blood was used for estimation of hemoglobin $(\mathrm{Hb})$ by Sahli's method and hematocrit by the micro-hematocrit method (Jain, 1986). The non-anticoagulated blood samples were centrifuged at $3000 \mathrm{rpm}$ for 15 minutes at room temperature to separate the serum. The serum samples were stored at $-20{ }^{\circ} \mathrm{C}$ until further analysis for glucose, serum proteins, urea, calcium, inorganic phosphorus and alkaline phosphatase (ALP) using commercial kits (Span Diagnostics Pvt. Limited, Surat, India). The thyroid hormones viz. tri-iodo-thyronine $\left(\mathrm{T}_{3}\right)$ and thyroxine $\left(\mathrm{T}_{4}\right)$ were also estimated in the serum samples adopting radioimmuno assay technique by using kits supplied by Bhabha Atomic Research Center (Mumbai, India). The ionic F concentration in serum samples was estimated by using $\mathrm{F}$ ion specific electrode (Cernik et al., 1970).

The data generated during the study were analyzed in a $3 \times 2$ design in order to ascertain the effects of protein, $F$, and their interaction, and presented as mean $\pm \mathrm{SE}$ in tables. The treatments were the main effects and the individual calf was considered the experimental unit. To test the effects of dietary protein, $\mathrm{F}$, and to ascertain the period effects, the following model was used:

$$
\mathrm{Y}_{\mathrm{ijkl}}=\mathrm{m}+\alpha_{\mathrm{i}}+\beta_{\mathrm{j}}+\alpha \beta_{\mathrm{ij}}+\mathrm{C}_{\mathrm{k}(\mathrm{ij})}+\tau_{1}+\alpha \tau_{\mathrm{il}}+\beta \tau_{\mathrm{jl}}+\alpha \beta \tau_{\mathrm{ijl}}+\varepsilon_{\mathrm{ijkl}} \text {, }
$$

where $\mathrm{Y}_{\mathrm{ijkl}}=$ the dependant variable; $\mathrm{m}=$ overall mean; $\alpha_{\mathrm{i}}=$ effect of dietary protein levels; $\beta_{\mathrm{j}}=$ effect of dietary $F$ levels; $\alpha \beta_{\mathrm{ij}}=$ interaction effect of protein and F levels; $\tau_{1}=$ the 1-th time measurement $\left(\tau_{1}\right)$ taken at the k-th calf; and $\varepsilon_{\mathrm{ijkl}}=$ residual error. In short, $\mathrm{Y}_{\mathrm{ijkl}}$ is the 1-th time measurement $\left(\tau_{1}\right)$ taken at the k-th calf receiving the i-th $\times$ $\mathrm{j}$-th combination of treatments $\alpha_{\mathrm{i}}$ and $\beta_{\mathrm{j}}$, respectively. The data was treated as repeated measure design since all the urinary $\mathrm{F}$ measurements and blood indices were carried out on similar animals. The means were subjected to test of significance by linear mixed model approach using the Statistical Package for Social Sciences (version 10.0). All statements of significance are based on $\mathrm{P}<0.05$ or $\mathrm{P}<0.01$ unless otherwise indicated.

\section{Results}

The CP contents of the diets varied as per the plan envisaged. The CP content in the composite diets was 12.3 , 10.1 and $15.1 \%$ for NP, LP and HP diets, respectively. The F content in the wheat straw was $17.4 \mathrm{mg} / \mathrm{kg}$. The F content of concentrate mixtures in control and supplements with inclusion of $F$ were $14.5,17.9$ and $15.1 \mathrm{mg} / \mathrm{kg}$, and 294.6, 302.2 and $299.4 \mathrm{mg} / \mathrm{kg}$ for NP, LP and HP diets, respectively (Table 2 ).

The initial pre-experimental value of urinary $\mathrm{F}$ level ranged from $2.85 \pm 0.23$ to $3.93 \pm 0.66 \mathrm{mg} / \mathrm{kg}$ in the animals allotted to different groups (Figure 1). Following six weeks of exposure, the $\mathrm{F}+$ animals had higher $(\mathrm{P}<0.01)$ urinary F $(12.11 \pm 0.97$ vs. $4.67 \pm 0.23 \mathrm{mg} / \mathrm{kg})$ level compared with the F- animals, and the same trend continued in subsequent collections. At 24 weeks of exposure, there was a significant $(\mathrm{P}<0.05)$ interaction between fluorine and protein levels in the diet with respect to urinary $\mathrm{F}$ excretion. The LPF+ animals have higher urinary $\mathrm{F}$ as compared with NPF+ animals but were not different from the $\mathrm{HPF}+$ group. Overall, $\mathrm{F}+$ animals excreted higher $(\mathrm{P}<0.05) \mathrm{F}$ in urine as compared with F- animals.

Regarding the data on blood biochemical profile along with thyroid hormones (Tables 3 and 4), no effects of dietary influence were evident on the levels of $\mathrm{Hb}$ and hematocrit, but period effects $(\mathrm{P}<0.01)$ were noticed for hematocrit, showing higher values at 2 nd collection than the 1st, 3rd and 4th collections. Likewise, for $\mathrm{Hb}$, lower values $(\mathrm{P}<0.05)$ were recorded during the 3 rd collection than other time points. Serum concentrations of glucose, total protein, albumin and globulin remained uninfluenced by the dietary treatments. However, period effects were observed for albumin and globulin levels, with higher $(\mathrm{P}<0.01)$ albumin levels at the 1 st measurement than others, and globulin levels were highest $(\mathrm{P}<0.01)$ during the $3 \mathrm{rd}$ and 4th measurements.

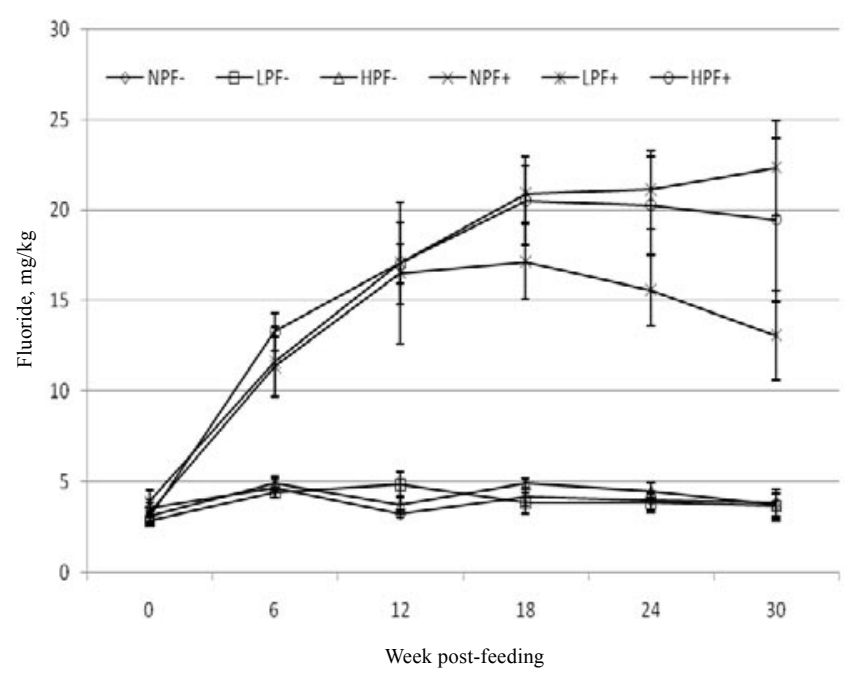

Significance: F effect: $\mathrm{P}<0.01$; Protein (P) effect: NS; $\mathrm{P} \times \mathrm{F}$ interaction effect: $\mathrm{P}<0.01$ only at 24 wk; Period effect: $\mathrm{P}<0.01$.

Figure 1 - Periodic changes in urinary excretion of fluoride by calves fed graded levels of protein (NP: normal protein; LP - low protein; HP - high protein) and fluorine (F-: 0, F+: $200 \mathrm{mg} / \mathrm{kg})$. 
Table 3 - Effect of different levels of protein and fluorine on selected blood biochemical parameters of crossbred calves

\begin{tabular}{|c|c|c|c|c|c|c|c|}
\hline \multirow{2}{*}{ Parameters ${ }^{1}$} & \multicolumn{3}{|c|}{ Fluorine $(0 \mathrm{mg} / \mathrm{kg})$} & \multicolumn{3}{|c|}{ Fluorine $(200 \mathrm{mg} / \mathrm{kg})$} & \multirow{2}{*}{ Significance $^{2}$} \\
\hline & NP & LP & HP & NP & LP & HP & \\
\hline Hemoglobin, $\mathrm{g} \mathrm{dL}^{-1}$ & $9.96 \pm 0.28$ & $10.85 \pm 0.29$ & $10.83 \pm 0.34$ & $11.05 \pm 0.28$ & $10.69 \pm 0.33$ & $10.33 \pm 0.27$ & NS T* \\
\hline Hematocrit, $\mathrm{g} \mathrm{dL}^{-1}$ & $29.50 \pm 0.97$ & $29.50 \pm 0.85$ & $32.30 \pm 1.12$ & $31.68 \pm 0.99$ & $30.75 \pm 1.27$ & $31.30 \pm 0.79$ & NS T** \\
\hline Glucose, $\mathrm{mg} \mathrm{dL}^{-1}$ & $57.04 \pm 2.41$ & $51.56 \pm 1.82$ & $50.64 \pm 1.72$ & $53.43 \pm 2.09$ & $53.28 \pm 2.63$ & $55.89 \pm 1.56$ & NS \\
\hline Total protein, $\mathrm{g} \mathrm{dL}^{-1}$ & $6.92 \pm 0.16$ & $6.86 \pm 0.24$ & $6.53 \pm 0.17$ & $6.50 \pm 0.20$ & $6.58 \pm 0.25$ & $6.55 \pm 0.14$ & NS \\
\hline Albumin, $\mathrm{g} \mathrm{dL}^{-1}$ & $3.44 \pm 0.14$ & $3.69 \pm 0.11$ & $3.64 \pm 0.14$ & $3.57 \pm 0.16$ & $3.37 \pm 0.15$ & $3.69 \pm 0.12$ & NS T** \\
\hline Globulin, $\mathrm{g} \mathrm{dL}^{-1}$ & $3.48 \pm 0.20$ & $3.17 \pm 0.27$ & $2.89 \pm 0.20$ & $2.92 \pm 0.23$ & $3.21 \pm 0.33$ & $2.86 \pm 0.18$ & NS T** \\
\hline Urea, $\mathrm{mg} \mathrm{dL}^{-1}$ & $19.20 \mathrm{~cd} \pm 1.2$ & $17.12 \mathrm{~d} \pm 1.2$ & $21.02 \mathrm{bcd} \pm 1.6$ & $19.13 \mathrm{~cd} \pm 1.7$ & $24.83 \mathrm{~b} \pm 2.4$ & $23.27 \mathrm{bc} \pm 1.7$ & $\mathrm{~F}^{* *} \mathrm{P} \times \mathrm{F}^{*} \mathrm{~T}^{* *}$ \\
\hline
\end{tabular}

${ }^{1}$ Mean of four periodic collections.

${ }^{2}$ Significant effect of fluoride $(\mathrm{F})$, protein $(\mathrm{P})$, or their interaction $(\mathrm{P} \times \mathrm{F})$.

NP - normal protein (100\%), LP - low protein (75\%); HP - high protein (125\%); NS - not significant; T - time or period effects.

bcd Different letters in the same row differ significantly $(* \mathrm{P}<0.05 ; * * \mathrm{P}<0.01)$.

Table 4 - Effect of different levels of protein and fluorine on selected minerals and thyroid hormones in the serum of crossbred calves

\begin{tabular}{|c|c|c|c|c|c|c|c|}
\hline \multirow{2}{*}{ Parameters $^{1}$} & \multicolumn{3}{|c|}{ Fluorine $(0 \mathrm{mg} / \mathrm{kg})$} & \multicolumn{3}{|c|}{ Fluorine $(200 \mathrm{mg} / \mathrm{kg})$} & \multirow{2}{*}{ Significance $^{2}$} \\
\hline & NP & LP & HP & NP & LP & HP & \\
\hline Calcium, mg dL ${ }^{-1}$ & $8.87 \pm 0.37$ & $8.84 \pm 0.47$ & $8.92 \pm 0.54$ & $7.81 \pm 0.40$ & $8.34 \pm 0.47$ & $7.96 \pm 0.36$ & $\mathrm{~F}^{* *} \mathrm{~T} * *$ \\
\hline Phosphorus, $\mathrm{mg} \mathrm{dL}^{-1}$ & $6.03 \pm 0.26$ & $6.52 \pm 0.38$ & $6.55 \pm 0.34$ & $6.24 \pm 0.33$ & $6.28 \pm 0.33$ & $6.53 \pm 0.29$ & NS T** \\
\hline ALP, $\mathrm{U} \mathrm{L}^{-1}$ & $138.6 b c \pm 14.2$ & $131.5 \mathrm{c} \pm 14.7$ & $144.2 b c \pm 11.2$ & $143.4 b c \pm 13.2$ & $172.7 \mathrm{~b} \pm 9.8$ & $147.5 b c \pm 12.4$ & $\mathrm{~F}^{* *} \mathrm{P} \times \mathrm{F}^{*} \mathrm{~T}^{* *}$ \\
\hline Fluoride, $\mathrm{mg} \mathrm{L}^{-1}$ & $0.497 \mathrm{c} \pm 0.01$ & $0.441 \mathrm{c} \pm 0.02$ & $0.389 \mathrm{c} \pm 0.01$ & $0.770 \mathrm{~b} \pm 0.07$ & $0.808 \mathrm{~b} \pm 0.08$ & $0.812 \mathrm{~b} \pm 0.06$ & $\mathrm{~F}^{* *} \mathrm{P} \times \mathrm{F}^{*} \mathrm{~T}^{* *}$ \\
\hline $\mathrm{T}_{3}, \mathrm{ng} \mathrm{mL}^{-1}$ & $1.47 \mathrm{~cd} \pm 0.1$ & $1.56 \mathrm{bc} \pm 0.1$ & $1.77 \mathrm{~b} \pm 0.1$ & $1.76 \mathrm{~b} \pm 0.1$ & $1.35 \mathrm{~d} \pm 0.1$ & $1.64 \mathrm{bc} \pm 0.1$ & $\mathrm{P} * \mathrm{P} \times \mathrm{F}^{* *} \mathrm{~T}^{* *}$ \\
\hline $\mathrm{T}_{4}, \mathrm{ng} \mathrm{mL}^{-1}$ & $25.76 \pm 2.60$ & $20.83 \pm 1.89$ & $26.76 \pm 3.41$ & $30.33 \pm 4.37$ & $25.22 \pm 3.66$ & $25.35 \pm 2.33$ & $\mathrm{P} * \mathrm{~T}^{* *}$ \\
\hline
\end{tabular}

${ }^{1}$ Mean of four periodic collections.

${ }^{2}$ Significant effect of fluoride $(\mathrm{F})$, protein $(\mathrm{P})$, or their interaction $(\mathrm{P} \times \mathrm{F})$.

NP - normal protein $(100 \%)$; LP - low protein (75\%); HP - high protein (125\%); ALP - alkaline phosphatase; NS - not significant; T - time or period effects.

bcd Different letters in the same row differ significantly $(* \mathrm{P}<0.05 ; * * \mathrm{P}<0.01)$.

The serum levels of urea showed the effect of $F$ addition having higher $(\mathrm{P}<0.01)$ levels in $\mathrm{F}+$ animals than their non-added counterparts. Protein levels imparted no effect but there was an interaction $(\mathrm{P}<0.05)$ effect, showing higher levels of urea in LPF + fed calves as compared with the others. Period effects were also observed, showing higher $(\mathrm{P}<0.05)$ levels in 2 nd period than $3 \mathrm{rd}$ and 4 th but not different from the 1st collection. Serum $\mathrm{Ca}$ levels were higher $(\mathrm{P}<0.01)$ in calves fed without $\mathrm{F}$ than groups that received it and highest $(\mathrm{P}<0.01)$ levels were obtained during the 1 st collection. The serum levels of $P$ were not affected by dietary treatments, but higher $(\mathrm{P}<0.01) \mathrm{P}$ levels were noticed during the 3 rd measurement than others showing period effects. Serum levels of ALP were higher $(\mathrm{P}<0.01)$ in $\mathrm{F}+$ animals than their $\mathrm{F}$ - counterparts. The mean serum ALP activity was higher $(\mathrm{P}<0.05)$ in $\mathrm{LPF}+$ $(172.71 \pm 9.76 \mathrm{IU} / \mathrm{L})$ than other treatment diets and lowest in LPF- (131.45 $\pm 14.70 \mathrm{IU} / \mathrm{L})$ calves. Also, ALP activity was higher $(\mathrm{P}<0.01)$ at the 1 st collection than other collection points, showing the effect of age.

The mean serum levels of $\mathrm{F}$ were higher $(\mathrm{P}<0.01)$ in $\mathrm{F}+$ animals than in their non-supplemented counterparts. As the duration of $\mathrm{F}$ exposure increased, the serum $\mathrm{F}$ levels increased in the supplemented groups (Figure 2). There was an interaction effect $(\mathrm{P}<0.05)$ between protein and $\mathrm{F}$ levels, showing higher levels in groups fed $\mathrm{F}$ than the ones that did not receive it. The period effects $(\mathrm{P}<0.01)$ were also noticed, revealing the highest serum $F$ levels in the 4th collection, followed by the $3 \mathrm{rd}$ and 2 nd periods and the lowest levels in the 1st collection. The mean serum $\mathrm{T}_{3}$ levels were lower $(\mathrm{P}<0.01)$ in $\mathrm{LPF}+$ animals $(1.35 \pm 0.08 \mathrm{ng} / \mathrm{mL})$ when compared with others, showing protein and $\mathrm{F}$ interaction. Lower $(\mathrm{P}<0.05) \mathrm{T}_{3}$ levels were also obtained in LP fed calves as compared with the NP and HP groups, showing

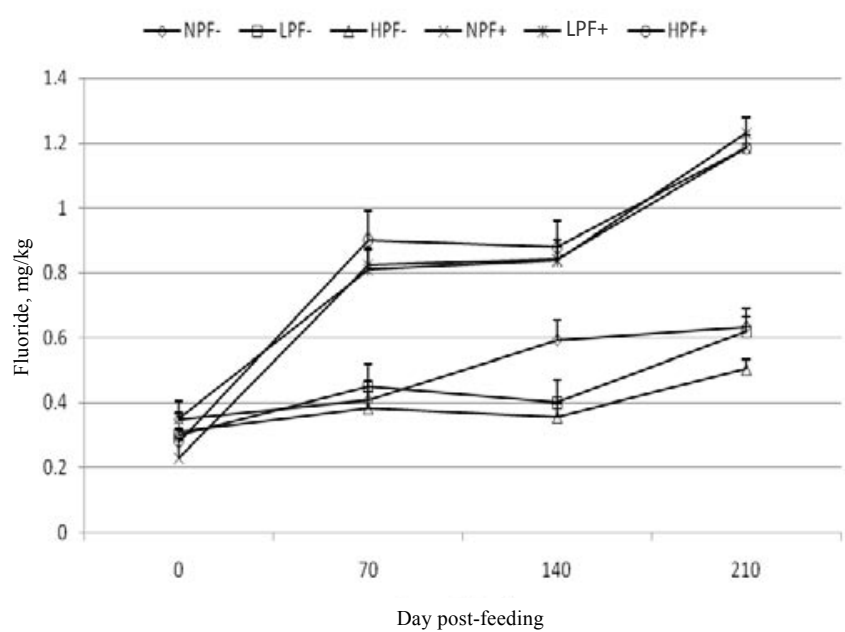

Significance: $\mathrm{F}$ effect: $\mathrm{P}<0.01$; Protein $(\mathrm{P})$ effect: NS; $\mathrm{P} \times \mathrm{F}$ interaction effect: $\mathrm{P}<0.05$; Period effect: $\mathrm{P}<0.01$.

Figure 2 - Periodic alterations in serum fluoride levels of calves fed graded levels of protein (NP - normal protein; LP low protein; HP - high protein) and fluorine (F-: $0, \mathrm{~F}+$ : $200 \mathrm{mg} / \mathrm{kg}$ ). 
the adverse effects of protein nutrition. The serum $\mathrm{T}_{4}$ levels were not affected by dietary treatments (Table 4); however, when protein levels were compared, similar trend was revealed like $\mathrm{T}_{3}$ of lower $(\mathrm{P}<0.05)$ values in $\mathrm{LP}$ than $\mathrm{NP}$ and HP groups. Period effects were also noticed for both $\mathrm{T}_{3}$ and $\mathrm{T}_{4}$ levels, showing highest $(\mathrm{P}<0.01)$ levels during the 3 rd period.

\section{Discussion}

After taking into consideration the total DM intake consisting of concentrate and wheat straw, the average $\mathrm{F}$ content of the ration was $16.0,17.7$ and $16.3 \mathrm{mg} / \mathrm{kg}$ for NP, LP and HP diets without F; however, it was 193.1, 186.8 and $173.4 \mathrm{mg} / \mathrm{kg}$ in NP, LP and HP supplemented with F, respectively. The dietary intake of $\mathrm{F}$ was $82.7,86.0$, and $82.6 \mathrm{mg} / \mathrm{d}$ and $615.8,579.8$ and $589.1 \mathrm{mg} / \mathrm{d}$ for NP, LP, and HP diets without and with F, respectively, which had been previously reported (Lohakare et al., 2010).

The periodic urinary $\mathrm{F}$ excretion pattern depicted that like all halides, $\mathrm{F}$ also has the tendency to be excreted through the urine. The urinary F level between 3 and $6 \mathrm{mg} / \mathrm{kg}$ is usually considered as normal (Wheeler \& Feel, 1983; Underwood, 1977), which matches the initial values in the present study. The urinary $\mathrm{F}$ levels were higher $(\mathrm{P}<0.01)$ in $\mathrm{F}+$ animals than in those without $\mathrm{F}$, and the trend continued at all measurements. The observed trend is similar to earlier reports (Yadav et al., 1996; Vashishth et al., 1997). The value above $7 \mathrm{mg} / \mathrm{kg}$ suggests F toxicity (Suttie, 1980; McDowell, 1992). No effect of dietary protein was evident on the urinary $\mathrm{F}$ excretion, except at 24 weeks, when an interaction $(\mathrm{P}<0.01)$ between protein and fluoride levels was evident, and animals on LP diet excreted considerable greater $(\mathrm{P}<0.01)$ amount of $\mathrm{F}$ when compared with those fed NP. The differences in urinary fluoride in the group fed $F$ rather than similarities in serum fluoride levels in these groups highlighted the differences in metabolism, and are the effect of different protein levels in the diet, a significant finding of this study. The present trend on the impact of dietary protein on urinary $\mathrm{F}$ excretion is in agreement with similar reports in rats (Boyde \& Cerklewski, 1987). It was reported that rats fed HP diets absorbed significantly $(\mathrm{P}<0.01)$ more $\mathrm{F}$ than rats fed LP diets, but the fraction of the absorbed $F$ that was actually retained was reduced $(\mathrm{P}<0.01)$ on HP feeding, because the decreased fecal $\mathrm{F}$ excretion was accompanied by higher urinary $\mathrm{F}$ excretion in HP diets (Boyde \& Cerklewski, 1987). However, in the present research, the HP diet did not appear to provide any protection. Overall, the high dietary protein had no influence on urinary $\mathrm{F}$ excretion.
The $\mathrm{Hb}$ values fall within the normal range of $8-13 \mathrm{~g} \mathrm{dL}^{-1}$. No variation was observed in blood levels of $\mathrm{Hb}$ and hematocrit when different protein levels or $\mathrm{F}$ levels were compared. Likewise, researchers have failed to observe any significant changes in $\mathrm{Hb}$ because of fluorosis in sheep (Weissova et al., 1998). However, some other reports have indicated a reduction in $\mathrm{Hb}$ level due to fluorosis (Swarup \& Singh, 1989; Metwalli et al., 1995; Jagdish et al., 1998). Similarly, various other researchers have reported reduction in hematocrit in fluorosed animals (Mohiuddin \& Reddy, 1989; Metwalli et al., 1995; Jagdish et al., 1998). Since F ion accumulates in bone tissues (Kassem et al., 1994), it could conceivably affect the formation of haematopoietic (bloodforming) cells in bone marrow cavities (Machalinski et al., 2000; Bouaziz et al., 2006). However, it appears that the adverse effects of $F$ on hematological indices are dependent upon the dose of the exposure, and the parameters were apparently not affected with the dose employed in the present experiment. As a matter of fact, it was also suggested that hemograms are highly variable and not valid for the diagnosis of fluoride toxicity (Karram \& Ibrahim, 1992).

The serum urea levels are within the normal range suggested for healthy cattle, but higher $(\mathrm{P}<0.01)$ levels were noted in the $\mathrm{F}+$ than the $\mathrm{F}$ - animals, similar to previous observations (Kessabi et al., 1983; Metwalli et al., 1995; Chlubek et al., 2003). However, when compared between different diets irrespective of periods, serum urea exhibited significant $(\mathrm{P}<0.05)$ difference among the groups, and the concentration was lower in LP than NP diet, but when $\mathrm{F}$ was added, the trend reversed, i.e., the serum urea increased more in LP than NP diets and the reasons remained obscure.

While the dietary protein level did not have any influence on serum $\mathrm{Ca}$ and inorganic $\mathrm{P}$ levels, lower $(\mathrm{P}<0.01)$ values of $\mathrm{Ca}$ were observed in $\mathrm{F}+$ animals when compared with their F- counterparts. Fluorine interacts and alters the metabolism of calcium and magnesium (Rich \& Ensinck, 1961). The decrease in serum calcium is related to a decrease of intestinal absorption of calcium by fluorine (Tao et al., 2006). The present findings are in parallel with those that reported reduction in serum $\mathrm{Ca}$ due to $\mathrm{F}$ exposure (Kessabi \& Ouhsine, 1986; Wang et al., 1992; Chandra, 1997; Tao et al., 2006; Madan et al., 2009). In contrast, Hillman et al. (1979) observed elevated levels of serum Ca in hydrofluorotic sheep. Again, some other researchers reported no effect in serum Ca due to F exposure (Wheeler et al., 1985; Vashishth et al., 1998). Similarly, the present observation on serum inorganic $\mathrm{P}$ was in line with earlier findings (Mehrotra \& Singh, 1989; Vashishth et al., 1998) although there are reports of the contrary (Wheeler et al., 1988; 
Wu et al., 1995; Chandra, 1997; Madan et al., 2009). The variations, therefore, could be related to the degree and duration of exposure to $\mathrm{F}$.

As was expected, the ALP activity was higher $(\mathrm{P}<0.01)$ in the $\mathrm{F}+$ than $\mathrm{F}$ - animals, as observed by many researchers with fluorosed animals (Swarup \& Singh, 1989; Wu et al., 1995; Tao et al., 2006; Madan et al., 2009). High ALP values on $\mathrm{F}+$ diets could be attributed to increase in the osteoblastic activity of the bone cells, which is directly correlated with increase in its level in blood. It was suggested that the increased serum ALP following fluorine exposure may reflect a toxicity of fluorine for both osteoblasts (bone forming cells) and resorbing osteocytes (Krook \& Ronald, 1998). Comparing different diets irrespective of periods, there was an interaction $(\mathrm{P}<0.05)$ between protein and $\mathrm{F}$ levels. Higher $(\mathrm{P}<0.05)$ level of ALP was noted in LPF+ fed animals than those under LPF- diets.

The serum levels of $\mathrm{F}$ were higher $(\mathrm{P}<0.01)$ in the animals receiving the F-added diet than their counterparts, as was expected. The results of the present study were in conformity with previous reports (Suttie \& Kolstad, 1977; Wheeler et al., 1985). Increase in the F levels was noted as the feeding period increased. The $\mathrm{F}$ levels of serum showed progressive increase with the duration of $\mathrm{F}$ feeding resulting in higher $(\mathrm{P}<0.01)$ values towards the end of the experimental period. The rise was sharpest from the first to second period, with the values almost doubling due to incorporation of $\mathrm{F}$. This could be due to failure of the body to activate the homeostatic mechanism when faced with sudden exposure to high levels of dietary F.

The serum levels of $T_{3}$ showed interaction $(\mathrm{P}<0.01)$ between the protein and $\mathrm{F}$ levels; the $\mathrm{T}_{3}$ levels went down significantly $(\mathrm{P}<0.01)$ on LP compared with the two other protein levels when $\mathrm{F}$ was added to the diets. It was also evident from data that HP diets, when compared between protein levels, induced greater serum $\mathrm{T}_{3}$ values than the LP diet, reflecting a positive correlation between protein level and serum $\mathrm{T}_{3}$. This showed that thyroid glands might have been activated to produce more $\mathrm{T}_{3}$ under the influence of the thyroid-stimulating hormone (TSH) because of availability of dietary protein. Comparison among the protein levels showed lower $(\mathrm{P}<0.05) \mathrm{T}_{4}$ values on LP diets compared with NP or HP diets. This further confirmed the trend observed in a study of different protein levels (Lohakare et al., 2006), indicating a positive correlation of thyroid hormones with dietary protein intake. However, no effect of $\mathrm{F}$ on thyroid hormones was noticed in the present study. This was contradictory to the findings of Wheeler \& Feel (1983), who reported a significant fall in $\mathrm{T}_{3}$ and $\mathrm{T}_{4}$ levels because of adverse impact of fluorosis on the thyroid glands. It was reported that $250 \mathrm{mg} / \mathrm{kg}$ and $400 \mathrm{mg} / \mathrm{kg} \mathrm{F}$ in diet significantly decrease serum $\mathrm{T}_{4}$ and $\mathrm{FT}_{4}$ levels and increase serum $\mathrm{TSH}$, but no significant differences were observed in serum $\mathrm{T}_{3}$ and $\mathrm{FT}_{3}$ after 50 days of treatment (Zhan et al., 2006). Similarly, Hillman et al. (1979) found decreased level of circulating $\mathrm{T}_{3}$ and $\mathrm{T}_{4}$ levels in cows with severe lesions of $\mathrm{F}$ toxicity, whereas other researchers found non-significant decrease in $\mathrm{T}_{4}$ values in buffaloes fed $\mathrm{F}$ at $60 \mathrm{mg} / \mathrm{kg}$ for 90 days (Madan et al., 2009). From these observations it appears that a decrease in thyroid hormone ensues only in case of severe $\mathrm{F}$ toxicity, which perhaps, may not be the case in the present study.

\section{Conclusions}

Incorporation of fluorine at $200 \mathrm{mg} / \mathrm{kg}$ in the diet of calves is reflected in its urinary excretion as well as serum level. However, inclusion of $200 \mathrm{mg}$ of fluorine $/ \mathrm{kg}$ of diet for up to 210 days does not change their serum biochemical profile. Furthermore, based on the urinary fluorine excretion pattern and serum fluorine levels, it can be deduced that the adverse effects of fluorine are apparently more severe in calves fed low protein diets.

\section{Acknowledgments}

The financial assistance to the first author in the form of Senior Research Fellowship, provided by the Indian Veterinary Research Institute (Izatnagar, India), is gratefully acknowledged.

\section{References}

BHARTI, V.K.; GUPTA, M.; LALL, D. Effect of boron as an antidote on dry matter intake, nutrient utilization and fluorine balance in buffalo (Bubalus bubalis) exposed to high fluoride ration. Biological Trace Element Research, v.126, suppl.1, p.S31-S43, 2008.

BOUAZIZ, H.; FETOUI, H.; KETATA, S. et al. Effects of sodium flouride ingested by lactating mice on some haemotological parameters in suckling pups and dams. Fluoride, v.39, p.211-219, 2006.

BOYDE, C.D.; CERKLEWSKI, F.L. Influence of type and level of dietary protein on fluoride bioavailability in the rat. Journal of Nutrition, v.117, p.2086-2090, 1987.

CERNIK, A.A.; COOKE, J.A.; HALL, R.J. Specific ion electrode in the determination of urinary fluoride. Nature, v.227, p.1260-1261, 1970 .

CHANDRA, S. Fluoride: Experimental toxicosis, toxicokinetics and immuno-modulation in goats. 1997. PhD Thesis. Indian Veterinary Research Institute, Izatnagar, India.

CHAUDHARY, V.; SHARMA, M.; YADAV, B.S. Assessment of water fluoride toxicity levels in northwest Rajasthan, India. Fluoride, v.41, p.212-215, 2008.

CHAUDHARY, V.; SHARMA, M.; YADAV, B.S. Elevated fluoride in canal catchment soils of northwest Rajasthan, India. Fluoride, v.42, p.46-49, 2009. 
CHEN, H.; HONG, J.; NIU, R. et al. Influence of fluoride on caspase3 expression in kidney of rats fed a normal or a low calcium and protein diet and its reversal by protein and calcium supplementation. Fluoride, v.42, p.121-126, 2009.

CHINOY, N.J.; MEHTA, D.; JHALA, D.D. Effects of different protein diets on fluoride-induced oxidative stress in mice testis. Fluoride, v.38, p.269-275, 2005a.

CHINOY, N.J.; MEHTA, D.; JHALA, D.D. Beneficial effects of a protein rich diet on fluoride induced free radical toxicity in mice liver. Fluoride, v.38, p.276-283, 2005 b.

CHINOY, N.J.; MEHTA, D.; JHALA, D.D. Effects of fluoride ingestion with protein deficient or protein enriched diets on sperm function of mice. Fluoride, v.39, p.11-16, 2006.

CHLUBEK, D.; GRUCKA-MAMCZAR, E.; BIRKNER, E. et al. Activity of pancreatic antioxidative enzymes and malondialdehyde concentrations in rats with hyperglycemia caused by fluoride intoxication. Journal of Trace Elements in Medicine and Biology, v.17, p.57-60, 2003.

CHOUBISA, S.L. Endemic fluorosis in southern Rajasthan, India. Fluoride, v.34, p.61-70, 2001.

CINAR, A.; SELCUK, M. Effects of chronic fluorosis on thyroxine, triiodothyronine, and protein-bound iodine in cows. Fluoride, v.38, p.65-68, 2005.

HE, Y.; NIU, R.Y.; WANG, J.M. et al. Effects of protein versus calcium supplementation on bone metabolism and development in fluoride-exposed offspring rats fed protein- and calcium-deficient diets. Fluoride, v.41, p.192-198, 2008.

HILLMAN, D.; BOLENBAUGH, D.L.; CONFEY, F.M. Hypothyroidism and anemia related to fluoride in dairy cattle. Journal of Dairy Science, v.62, p.416-423, 1979.

JAGADISH, S.; SINGH, L.K.; SAMAD, A. et al. Bovine Fluorosis I: Clinical pathology and investigations into source of fluorine. Indian Veterinary Journal, v.75, p.335-337, 1998.

JAIN, N.C. Veterinary hematology. 4.ed. Philadelphia: Lea and Febiger Publishers, 1986. 1221p.

JUNKKARINEN, K.; KREULA, M. The metabolism of fluoride by cows on protein free and normal feed. Meijeritieteellinen Aikakauskirja, v.34, p.31-39, 1976.

KARRAM, M.H.; IBRAHIM, T.A. Effect of industrial fluorosis on hemogram of camels. Fluoride, v.25, p.23-36. 1992.

KASSEM, M.; MOSEKILDE, L.; ERIKSEN, E.F. Effects of sodium fluoride on human bone cells in vitro: differences in responsiveness between stromal osteoblast precursors and mature osteoblasts. European Journal of Endocrinology, v.130, p.381-386, 1994.

KEARL, L.C. Nutrient requirement of ruminants in developing countries. Logan, Utah: International Feedstuffs Institute, Utah Agricultural Experiment Station, Utah State University, 1982. $381 \mathrm{p}$.

KESSABI, M.; BONDARINE, B.; BRAUN, J.P. et al. Serum biochemical effects of fluoride in sheep of Darmous area. Fluoride, v.16, p.214-219, 1983

KESSABI, M.; OUHSINE, A. Fluorosis in sheep in phosphate rich regions. Epidemiological, clinical, biochemical aspects. Magbreb Veterinaire, v.2, p.51-52, 1986.

KROOK, L.; RONALD, R.M. Fluoride and alkaline phosphatase. Fluoride, v.31, p.177-182, 1998.

LOHAKARE, J.D.; PATTANAIK, A.K.; KHAN, S.A. Effect of dietary protein levels on the performance, nutrient balances, metabolic profile and thyroid hormones of crossbred calves. Asian-Australasian Journal of Animal Sciences, v. 19, p.1588-1596, 2006.

LOHAKARE, J.D.; PATTANAIK, A.K.; KHAN, S.A. Effect of longterm fluoride exposure on growth, nutrient utilization and fluoride kinetics of calves fed graded levels of dietary protein. Biological Trace Element Research, v.138, p.148-162, 2010.

LOHAKARE, J.D.; PATTANAIK, A.K.; KHAN, S.A. Metabolic effects of short-term administration of fluoride to calves fed graded protein levels in their diets. Fluoride, v.44, p.95-102, 2011.

MACHALINSKI, B.; ZEJMO, M.; STECEWICZ, I. et al. The influence of sodium fluoride on the clonogenecity of human hematopoietic progenitor cells: preliminary report. Fluoride, v.33, p.168-173, 2000.

MADAN, M.; PURI, J.P.; SINGH, J.K. Growth, feed efficiency and blood profile of buffalo calves consuming high levels of fluoride. Tropical Animal Health and Production, v.41, p.295-298, 2009.

McDOWELL, L.R. Minerals in animal and human nutrition. New York: Academic Press, 1992. 524p.

MEHROTRA, M.L.; SINGH, R. Chronic fluorosis in a goat farm. Indian Journal of Animal Science, v.59, p.801-810, 1989.

METWALLI, A.A.; EL-GHARIEB, S.A.; ASHRY, K.M. Clinical and laboratory investigations on chronic bovine fluorosis. In: PROCEEDINGS OF THE THIRD SCIENTIFIC CONGRESS OF EGYPTIAN SOCIETY FOR CATTLE DISEASES. Assiut-Egypt, 1995. v.2, p.331-335.

MOHIUDDIN, S.M.; REDDY, M.V. Hematological and biochemical studies on fluoride toxicity in sheep. Indian Veterinary Journal, v.66, p.1089-1091, 1989.

NATIONAL ACADEMY OF SCIENCES - NAS. Effects of fluoride in animals. Washington, D.C.: National Research Council, 1974. p.23.

PARKER, C.M.; SHARMA, R.P.; SHUPE, J.L. The interaction of dietary vitamin $\mathrm{C}$, protein and calcium with fluoride toxicity (fluoride effects and nutritional stress). Fluoride, v.12, p.144-154, 1979.

RAGHAVACHARI, S.; TRIPATHI, R.C.; BHUPATHI, R.K. Endemic fluorosis in five villages of the palamau district, Jharkhand, India. Fluoride, v.41, p.206-211, 2008.

RICH, C.; ENSINCK, J. Effect of sodium fluoride on calcium metabolism in human beings. Nature, v.191, p.184-185, 1961.

RYS, R. Tests of feed phosphates of different $F$ contents and defluorinated by heating on gains, digestibility, carcass quality and F content of the bones in fattening pigs from $30-90 \mathrm{~kg}$ live weight. Jahrbuch-fur-Tierernahrung-und-Futterung, v.8， p.328-339, 1973.

SUTTIE, J.W.; KOLSTAD, D.L. Effect of dietary fluoride ingestion on ration intake and milk production. Journal of Dairy Science, v.60, p.1568-1573, 1977.

SUTTIE, J.W. Nutritional aspects of fluoride toxicosis. Journal of Animal Science, v.51, p.759-766, 1980.

SWARUP, D.; SINGH, Y.P. Bovine fluorosis in a brick kiln-congested zone. Indian Journal of Veterinary Medicine, v.9, p.12-14, 1989.

TAO, X.; XU, Z.R.; WANG, Y.Z. Effects of dietary fluoride levels on growth, serum indexes and antioxidant systems in growing pigs. Turkish Journal of Veterinary and Animal Sciences, v.30, p.65-70, 2006

TUSL, J. Direct determination of fluoride in phosphate materials in mineral feeds with the fluoride ion activity electrode. Journal of AOAC International, v.53, p.267-269, 1970.

TUSL, J. Fluoride ion activity electrode as a suitable means for direct determination of urinary fluoride. Analytical Chemistry, v.44, p.1693-1698, 1972.

UNDERWOOD, E.J. Trace elements in human and animal nutrition. 4.ed. New York: Academic Press, 1977. 545p.

VASHISHTH, S.N.; KAPOOR, V.; YADAV, P.S. et al. Effect of supplemental boron on nutrient utilization, mineral status and blood biochemical constituents in lambs fed high fluorine diet. Fluoride, v.30, p.165-172, 1997.

VASHISHTH, S.N.; KAPOOR, V.; LALL, D. et al. Mineral status and serum alkaline phosphatase activity in lambs fed diets supplemented with fluorine and boron. Indian Veterinary Journal, v.75, p.17-21, 1998.

VILLA, A.E. Rapid method for determining fluoride in vegetation using an ion selective electrode. Analyst, v.104, p.545-551, 1979.

WANG, J.D.; ZHAN, C.W.; CHEN, Y.F. et al. A study of damage to hard tissue of goats due to industrial fluoride pollution. Fluoride, v.25, p.123-128, 1992.

WANG, J.D.; HONG, J.H.; LI, J.X. et al. The effect of nutrition supplementation during the annual dry grass season on tooth wear in industry-fluorosed goats. Fluoride, v.27, p.136-140, 1994. 
WANG, J.; NIU, R.; SUN, Z. et al. Effects of protein and calcium supplementation on bone metabolism and thyroid function in protein and calcium deficient rabbits exposed to fluoride. Fluoride, v.41, p.283-291, 2008.

WANG, H.; YANG, Z.; ZHOU, B. et al. Fluoride-induced thyroid dysfunction in rats: roles of dietary protein and calcium level. Toxicology and Industrial Health, v.25, p.49-57, 2009.

WEISSOVA, T.; BIRES, J.; NAGY, O. Experimental chronic fluorosis in sheep. Slovensky-Veterinarsky-Casopis, v.23, p.219-222, 1998.

WHEELER, S.M.; FEEL, L.R. Fluorides in cattle nutrition-a review. Nutrition Abstracts and Reviews, v.53, p.741-769, 1983.

WHEELER, S.M.; BROCK, T.B.; TEASDALE, D.C. Effects of added $30 \mathrm{mg}$ fluoride/L drinking water given to pregnant ewes and their lambs upon physiology and wool growth. The Journal of Agricultural Science Cambridge, v.105, p.715-726,1985.
WHEELER, S.M.; TURNER, A.D.; BROCK, T.B. et al. The effect of added $30 \mathrm{mg} / \mathrm{L}$ fluoride in drinking water on ewes and their lambs and current bone levels of sheep in N.S.W. Australia. Fluoride, v.21, p.60-68, 1988.

WU, Z.J.; DING, J.Y.; QI, D.S. et al. Biochemical indices of buffalo with fluorosis and their significance for diagnosis. Journal of Huazhong Agricultural University, v.14, p.369-373, 1995.

YADAV, P.S.; KAPOOR, V.; MANDAL, A.B. Effect of boron supplementation on growth, nutrient digestibility and fluorine balance in lambs fed fluorine rich diet. Indian Journal of Animal Sciences, v.66, p.1055-1059, 1996.

ZHAN, X.A.; LI, J.X.; WANG, M. et al. Effects of fluoride on growth and thyroid function in young pigs. Fluoride, v.39, p.95-100, 2006. 